\title{
Nitrogen deposition drives the carbon sink of temperate and boreal forests
}

\section{Giacomo Grassi}

\begin{abstract}
A comment is provided on the paper by Magnani et al. on the human influences in the carbon cycle of forests, just published in Nature. The results illustrated by the paper are discussed in the context of the recent scientific and politic debate on the role of carbon sinks in mitigating climate change.
\end{abstract}

Keywords: Human footprint, Carbon cycle, Chronosequence, Nitrogen.

Citation: Grassi G, 2007. Nitrogen deposition drives the carbon sink of temperate and boreal forests. Forest@ 4 (2): 144146. [online] URL: http://www.sisef.it/.

It is well known that temperate and boreal forests in the Northern Hemisphere have an important role in sequestering carbon from the atmosphere, although with a large interannual variability. Among the possible drivers of this carbon sink, it is generally assumed a significant effect of forest expansion. However, the relative contribution of other important factors, such as forest management (direct human effect), increase in atmospheric $\mathrm{CO}_{2}$, increasing temperatures and nitrogen deposition (indirect human effects), is still matter of a controversial debate.

The relevance of this discussion is not only academic, but goes to the heart of the current climate change debate for at least two reasons. The first reason is primarily scientific: the attribution of carbon (C) fluxes to their underlying drivers is a prerequisite to understanding the terrestrial biosphere's potential to slow future atmospheric $\mathrm{CO}_{2}$ rise.

The second reason is more political. After the Kyoto Protocol decided to account for the bioshperic carbon sink due to "direct human-induced effects", a need clearly emerged for improved scientific understanding in support of effective climate change mitigation policies. As a result, the Intergovernmental Panel on Climate Change (IPCC) was invited "to develop practicable methodologies to factor out direct human-induced effect on terrestrial carbon sink from indirect human-induced and natural effects (such as those from $\mathrm{CO}_{2}$ fertilization and $\mathrm{N}$ deposition)". The answer was that the scientific community did not have yet the sufficient understanding to provide the requested methodology (IPCC 2003). In the light of the recently started discussion on post-Kyoto agreements, the partitioning of natural, indirect and direct human induced effects on terrestrial carbon sinks re- mains a necessary step for any future $\mathrm{C}$ accounting scheme that aims to establish a clear and unambiguous connection between human activities and C credits (Canadell et al. 2007).

Within this "partitioning debate", the effect of nitrogen $(\mathrm{N})$ deposition appears particularly controversial, and for this reason it is poorly incorporated in the models of future terrestrial sink (Hungate et al. 2003). Excluding the cases of very high $\mathrm{N}$ inputs which are know to promote complex alterations to soil and plant biogeochemistry, ultimately leading to forest decline and soil acidification -, several studies suggested that moderate $\mathrm{N}$ deposition levels on forests may significantly enhance carbon sequestration, particularly in mid and high-latitude forests. Of course, when water and other nutrients become more limiting relative to $\mathrm{N}$, ecosystems progressively approach $\mathrm{N}$ saturation. The controversial point is if temperate and boreal forests are already facing $\mathrm{N}$ saturation or not. The relevance of the current $\mathrm{N}$ deposition in the enhancement of carbon sink has been recently questioned by both experimental and modeling studies (e.g., Nadelhoffer et al. 1999, De Vries et al. 2006). Similarly, other studies suggested that, if $\mathrm{N}$ supply was a limiting factor before the 1970s, the progressive eutrophication has eliminated this limitation (Pinto et al. 2007).

A paper just published by Nature (Magnani et al. 2007) provides a fresh look into this debate. Through an elegant analysis of data from twenty cronosequences (both from the Carbo-Europe project and from the literature), the authors conclude suggesting an overwhelming effect of $\mathrm{N}$ deposition on carbon sequestration of temperate and boreal forests. The use of the chronosequences allowed the authors to 
calculate the average ecosystem $C$ fluxes over the entire rotation (i.e., Gross Primary Production, GPP, Ecosystem Respiration, RE, and Net Ecosystem Production, NEP = GPP-RE), thus filtering out the (otherwise predominant) effects of age. Both GPP and RE correlated positively with mean annual temperature, but NEP did not. In contrast, NEP was found to be highly and positively correlated to $\mathrm{N}$ wet deposition, with a surprisingly high return in term of $C$ sequestration (400 $\mathrm{kg}$ of additional C per every $\mathrm{kg}$ of extra $\mathrm{N})$. These results, while confirming a major control of temperature on soil organic matter decomposition, suggest that $\mathrm{N}$ deposition (largely resulting from human activities) significantly altered the balance between GPP and RE in favour of the former. Furthermore, no apparent sign of $\mathrm{N}$ saturation was observed within the range of $\mathrm{N}$ deposition examined (up to $15 \mathrm{Kg} \mathrm{N} \mathrm{ha}^{-1} \mathrm{yr}^{-1}$ of total deposition).

While providing new and interesting results, the paper inevitably leaves several questions open. For example, are the experimental sites selected for the paper sufficiently representative of the temperate and boreal forests? Clearly, other studies are needed to confirm or not the observed trends, possibly including aspects often neglected in the past (e.g., the relevance of canopy $\mathrm{N}$ absorption).

Average NEP was found to be highly correlated to maximum NEP. If this relationship will be confirmed, a close relationship would also be expected between maximum NEP (easier to collect than average NEP) and $\mathrm{N}$ deposition.

The $\mathrm{N}$-induced imbalance of the photosynthesis vs. respiration equilibrium (at the ecosystem level) found by Magnani et al. seems independent of the species. At the leaf level, however, deciduous hardwood species are known to have a steeper photosynthesis/ $\mathrm{N}$ relationship than evergreen conifers (e.g., Reich et al. 1998). Although the scale of analysis is different, this could suggest interspecific differences in the relationship between $\mathrm{N}$ deposition and respiration.

How $\mathrm{N}$ deposition interacts with other environmental relevant factors? For example, $\mathrm{N}$ deposition is spatially correlated with increased atmospheric ozone, which is known to have a detrimental effect on plant growth. Will the likely higher frequency of severe drought in the future counteract the positive effects of $\mathrm{N}$ deposition?

Although the issue would clearly require a more comprehensive analysis, the paper of Magnani et al. has the merit to challenge the widespread assumption of nearly N-saturated forest ecosystems and, at the same time, to suggest directions for further investigations. For example, the use of the average NEP seems a very promising approach. Setting up chronosequences to asses the $C$ sink is certainly more expensive than the traditional "spotty" measurements, but the more powerful information that could be retrieved by factoring out the effect of age may well be worth the extra effort.

Finally, although we are still far from being able to provide "practicable methodologies to factor out direct from indirect human-induced effects on terrestrial carbon sinks" (as requested to IPCC), the paper of Magnani et al. will certainly stimulate further steps forward. The currently increasing interest in the partition of the different effects is welcomed and should be further encouraged, because it may help to reduce the risk of "undue credits" in future climate negotiations, i.e., to avoid that a carbon sink largely resulting from an indirect human effect is improperly used to escape from real reduction of emissions.

\section{References}

Canadell JG, Kirschbaum MUF, Kurz WA, Sanz MJ, Schlamadinger B, Yamagata Y (2007). Factoring out natural and indirect human effects on terrestrial carbon sources and sinks. Environmental Science and Policy 10: 370-384.

De Vries W, Reinds GJ, Gundersen P, Sterba H (2006). The impact of nitrogen deposition on carbon sequestration in European forests and forest soils. Global Change Biology 12: 1151-1173.

Hungate BA, Dukes JS, Shaw MR, Luo YQ, Field CB (2003). Nitrogen and climate change. Science 302: 15121513.

IPCC (2003). Current scientific understanding of the processes affecting terrestrial carbon stocks and human influences upon them. Science Statement. Expert Report. IPCC Meeting, July 21-23, 2003, Geneva.

Magnani F, Mencuccini M, Borghetti M, Berbigier $P$, Berninger F, Delzon S, Grelle A, Hari P, Jarvis PG, Kolari P, Kowalski AS, Lankreijer $H$, Law BE, Lindroth A, Loustau D, Manca G, Moncrieff JB, Rayment M, Tedeschi V, Valentini R, Grace J (2007). The human footprint in the carbon cycle of temperate and boreal forests. Nature 447 : 848-850.

Nadelhoffer KJ, Emmett BA, Gundersen P, et al (1999). Nitrogen deposition makes a minor contribution to carbon sequestration in temperate forests. Nature 398: 145-148.

Pinto PE, Gégout JC, Hervé JC, Dhôte JF (2007) Changes in environmental controls on the growth of Abies alba Mill. in the Vosges Mountains, north-eastern France, during the $20^{\text {th }}$ century. Global Ecology and Biogeography 16 : 472-484. 
Reich PB, Ellsworth DS, Walters MB (1998) Leaf structure (specific leaf area) modulates photosynthesis-nitrogen relations: evidence from within and across species and functional groups. Functional Ecology 12: 948-958.

\section{Author's Box}

Giacomo Grassi, laureato in Scienze Agrarie e dottore di ricerca in Colture Arboree, è funzionario scientifico della Commissione Europea, DG Centro Comune di Ricerca, Istituto per l'Ambiente e la Sostenibilità, Unità "Cambiamenti Climatici"- Ispra (VA); i suoi interessi di ricerca spaziano nei campi dell'ecofisiologia forestale, della selvicoltura e dei cambiamenti climatici. E-mail: giacomo.grassi@jrc.it 